\title{
Post-exercise hypotension in concurrent training: a systematic review
}

\section{A hipotensão pós-exercício no treinamento concorrente: uma revisão sistemática}

\section{Diego De Mello}

(D) https://orcid.org/0000-0002-9186-4191

Thatiane Lopes Valentim Di Paschoale Ostolin ${ }^{1,2}$

(D) https://orcid.org/0000-0002-8492-2840

Abstract - Physical exercise is capable to reduce blood pressure (BP) acutely in a phenomenon described as post-exercise hypotension (PEH). However, the acute effect of concurrent training on PEH needs clarification. The present review aimed to verify and summarize the acute effect of concurrent training on $\mathrm{PEH}$ in normotensive and hypertensive subjects. The search was carried out in the databases PubMed, Scielo, and Lilacs, and resulted in 3806 articles. Only 14 studies met the eligibility criteria and were selected. According to included studies, concurrent training can promote $\mathrm{PEH}$ regardless of the order, volume, and intensity prescribed, being an effective strategy in the control of arterial hypertension. There is no consensus in the literature regarding the best prescription strategy, as well as the order of execution of the types of exercis

Key words: Blood pressure; Exercise; Post-exercise hypotension; Systematic review.

Resumo - O exercício físico tanto aeróbio como de força é capaz de reduzir a pressão arterial $(P A)$ de forma aguda em um fenômeno descrito como bipotensão pós-exercício (HPE). Contudo, ainda não está claro o efeito agudo do treinamento concorrente na indução da HPE. A presente revisão teve por objetivo verificar e sumarizar o efeito agudo do treinamento concorrente na HPE em individuos normotensos e hipertensos. A busca foi realizada nas bases de dados, PubMed, Scielo e Lilacs e resultou em 3806 artigos. Somente 14 estudos atenderam aos critérios de inclusão e foram selecionados. Segundo os artigos incluidos, o treinamento concorrente é capaz de gerar HPE independente da ordem de execução, do volume e da intensidade prescritas, sen do uma eficiente estratégia no controle da hipertensão arterial sistêmica. Não há consenso na literatura em relação a melhor estratégia de prescrição, bem como ordem de execução dos exercícios.

Palavras-chave: Exercício físico; Hipotensão pós-exercício; Pressão sanguinea; Revisão sistemática.

1 Federal University of São Paulo. Department of Human Movement Sciences. Post-Graduation Program in Exercise Physiology Applied to the Clinic. Institute of Health and Society. Santos, SP. Brazil.

2 Federal University of São Paulo. Department of Human Movement Sciences. Laboratory of Epidemiology and Human Movement. Santos, SP. Brazil.

Received: November 25, 2019 Accepted: May 16, 2020

How to cite this article Mello DD, Ostolin TLVDP. Postexercise hypotension in concurrent training: a systematic review. Rev Bras Cineantropom Desempenho Hum 2020, 22:e72211. DOl: http://dx.doi. org/10.1590/1980-0037.2020v22e72211.

Copyright: This work is licensed under a Creative Commons Attribution 4.0 International License. 


\section{INTRODUCTION}

Cardiovascular diseases (CVD) are a major public health problem. According to recent data from the World Health Organization ${ }^{1}, \mathrm{CVD}$ is the leading cause of death in the world. One of the main risk factors associated with the development of CVD is arterial hypertension, which increased prevalence in the past few years ${ }^{2}$. Arterial hypertension affects more than $32 \%$ of Brazilian adults ${ }^{2}$ with high prevalence in the elderly and women ${ }^{3,4}$.

Currently, arterial hypertension is characterized by a sustained elevation in blood pressure (i.e., systolic blood pressure $\geq 140 \mathrm{mmHg}$ and/or diastolic blood pressure $\geq 90 \mathrm{mmHg})^{2}$. Arterial hypertension is considered the most treatable and preventable morbidity among risk factors for developing CVD. However, the arterial hypertension treatment costs generate a high impact on the loss of labor productivity and family income, estimated in Brazil at more than $\mathrm{R} \$ 12$ billion between 2006 and $2015^{5}$. Thus, preventing arterial hypertension is an important and urgent priority of public health.

Lifestyle changes (i.e., including a lower intake of sodium, alcohol and fat, smoke cessation, and physical activity) are the main strategy for the control and prevention of arterial hypertension ${ }^{2}$. Among the behavioral factors, physical activity has been widely investigated in arterial hypertension management. Both aerobic training ${ }^{6-10}$ and strength training ${ }^{11-14}$ are able to reduce blood pressure chronically, as well as acute effect know as post-exercise hypotension $(\mathrm{PEH})^{15}$. Although the literature addressed the efficacy of aerobic and strength training on hypertension treatment, the concurrent training (a combination of aerobic and strength training within the same session or in separate sessions) must be equally investigated.

Thus, it is necessary to summarize the existing literature that investigated the acute effects of concurrent training on blood pressure measurements. Also, it is important to explore whether aspects of concurrent training promote major PEH in comparison with other training models. Such information will help to provide an evidence-based for public health policy in order to recommend the concurrent training for prevention and treatment for arterial hypertension. The purpose of the present study was to review and synthesize the acute effects of concurrent on PEH in hypertensive and normotensive adults.

\section{METHOD}

\section{Design and search strategy}

This review follows the Preferred Reporting Items for Systematic reviews and Meta-Analyses (PRISMA) statement ${ }^{16}$. The search was performed in the following electronic databases: PubMed, Scielo, and Lilacs. We restricted to publications in English or Portuguese language until June 2019. The search strategy included a combination of keywords: post-exercise hypotension, post-exercise hypotensive response, blood pressure lowering, 
concurrent training, exercise training, exercise, as follows:

"Post-exercise hypotension" AND “Concurrent training" AND "Exercise training" AND "exercise"- "Post-exercise hypotensive response" AND "Concurrent training" AND "Exercise training" AND "exercise""Blood pressure-lowering" AND "Concurrent training" AND "Exercise training” AND “exercise”- "Post-exercise hypotension" OR "Post-exercise hypotensive response" OR blood pressure lowering.

\section{Eligibility criteria}

We included randomized clinical trials. Studies with human subjects over 18 -yrs from both males and females were considered eligible. Studies that analyzed the acute effects of concurrent training compared to other training models on the blood pressure of hypertensive and normotensive subjects were also considered eligible. However, studies that did not present blood pressure measures before and after training for at least 30 minutes were excluded.

\section{Data extraction}

The screening in titles and abstracts was performed by one reviewer (DM) in order to identify potentially eligible studies. The full-texts were also assessed and considered according to the inclusion and exclusion criteria of this review. Then, the reviewer extracted data from included studies. Another reviewer (TLVPO) checked the information for completion and accuracy. The following information was extracted from the studies: sample size, mean age, rest blood pressure, training protocol, and main results.

\section{Appraisal of study quality}

Two independent reviewers (DM and TLVPO) assessed the methodological quality of the included studies by using the risk of bias Physiotherapy Evidence Database (PEDro) scale ${ }^{17}$.

\section{RESULTS}

Initially, the search identified 3806 potential citations (Figure 1). After removing the duplicates, 2587 articles remained for analysis. Then, 2545 were excluded based on titles and abstracts. Another 28 citations were excluded, respectively 20 article reviews, 04 studies that did not evaluate acute effect on blood pressure, and other 04 that did not compare concurrent training with other training models.

Thus, fourteen studies met the inclusion criteria and were included in this review.

The articles included were published from 2011 to 2017. Ten studies were conducted with normotensive subjects. Also, four studies presented hypertensive subjects. The age group ranged from 20 to 65 years, 286 subjects participated in the studies, 122 men and 164 women, 177 normotensive, and 109 hypertensive subjects. All studies are randomized controlled trials that observed the acute effect of a single exercise session. Training 


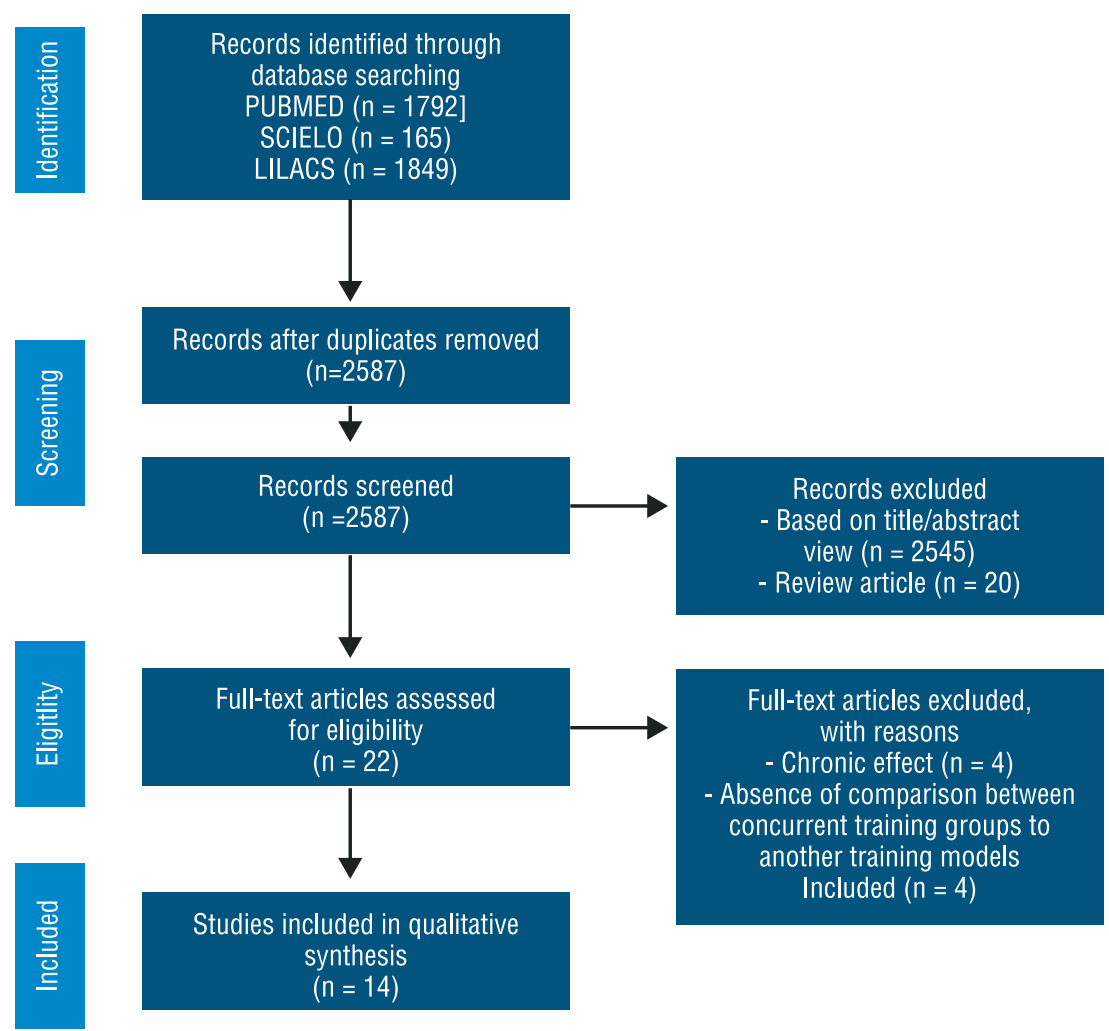

Figure 1. Flowchart of the systematic review.

protocol presented duration from 45 to 60 minutes. The aerobic training was performed at $40-80 \%$ of peak $\mathrm{VO}_{2}, 50-70 \%$ of heart rate reserve, $40-75 \%$ of maximal heart rate. The strength training was performed at $40-80 \%$ of 1 repetition maximum.

The blood pressure was measured after 30, 60, and 120 minutes of the end of the training, as well as 6 hours and 24 hours later. Systolic blood pressure ranged from 111 to $162 \mathrm{mmHg}$ and diastolic blood pressure ranged from 68 to $95 \mathrm{mmHg}$.

The main characteristics of the studies included are available in Table 1.

The studies showed higher $\mathrm{PEH}$ when aerobic training was performed before strength training compared to the opposite ${ }^{19,20}$. However, the other four studies did not find differences regarding the order of execution of concurrent training ${ }^{21-24}$. When high intensity, great $\mathrm{PEH}^{25,26}$.

The duration of $\mathrm{PEH}$ was longer after concurrent training in comparison to other training models ${ }^{27-29}$. Greater magnitude $\mathrm{PEH}$ was observed for aerobic training compared to concurrent training ${ }^{27}$ and for concurrent training in comparison to strength training ${ }^{11}$. Saccomani et al. ${ }^{22}$ found higher and longer PEH for concurrent training compared to aerobic and strength training. However, Ruiz et al. ${ }^{30}$ did not observed any difference between groups (e.g., aerobic, strength, and concurrent). Results from Santos et al. ${ }^{31}$ showed greater $\mathrm{PEH}$ when performed eccentric strength training prior to aerobic training in comparison to traditional strength training prior to aerobic training. 
Table 1. Description of the selected studies on participants' characteristics, training protocol and post-exercise hypotension.

\begin{tabular}{|c|c|c|c|c|c|c|}
\hline \multirow{2}{*}{ Study } & \multirow{2}{*}{ Participants } & \multicolumn{2}{|c|}{ Rest Blood Pressure } & \multirow{2}{*}{ - Training protocol } & \multirow{2}{*}{ Duration } & \multirow{2}{*}{ Results } \\
\hline & & SBP & $\mathrm{DBP}$ & & & \\
\hline $\begin{array}{l}\text { Keese et } \\
\text { al. }^{28}\end{array}$ & $\begin{array}{l}21 \text { normo- } \\
\text { tensive men } \\
(20.7 \pm 0.7 \\
y r)\end{array}$ & $\begin{array}{l}111.52 \pm 2.56 \\
\mathrm{~mm} \mathrm{Hg}\end{array}$ & $\begin{array}{l}73.86 \pm \\
3.62 \mathrm{~mm} \mathrm{Hg}\end{array}$ & $\begin{array}{l}\text { CG: } 60 \text { min rest } \\
\text { AG: } 60 \text { min cycle ergometer at } \\
65 \% \mathrm{VO}_{2 \text { peak }} \\
\text { ST: } 8 \text { strength exercises in } 3 \text { sets } \\
\text { of } 6-8 \text { rep at } 80 \% 1 \mathrm{RM} \\
\text { CTG: } 6 \text { strength exercises in } 2 \\
\text { sets at } 80 \% 1 \mathrm{RM}+30 \text { min cycle } \\
\text { ergometer at } 65 \% \mathrm{VO}_{2 \text { peak }}\end{array}$ & $\begin{array}{l}\text { BP monitoring } \\
\text { for } 120 \mathrm{~min}\end{array}$ & $\begin{array}{l}\text { Magnitude reduc- } \\
\text { tion BP similar to } \\
\text { AG, ST, CTG } \\
\text { Longer PEH dura- } \\
\text { tion in SBP for AG, } \\
\text { CTG. } \\
\text { Longer PEH dura- } \\
\text { tion in DBP for AG. }\end{array}$ \\
\hline $\begin{array}{l}\text { Ferrari et } \\
\text { al. }^{29}\end{array}$ & $\begin{array}{l}20 \text { hyper- } \\
\text { tensive men } \\
(65.3 \pm 3.3 \mathrm{yr})\end{array}$ & $\begin{array}{l}120 \pm 13 \mathrm{~mm} \\
\mathrm{Hg}\end{array}$ & $\begin{array}{l}71 \pm 10 \mathrm{~mm} \\
\mathrm{Hg}\end{array}$ & $\begin{array}{l}\text { CG: } 45 \text { min rest } \\
\text { AG: } 45 \text { min treadmill at } 65-70 \% \\
\text { VO }{ }_{2 \max } \quad \text { CTG: } \\
4 \text { strength exercises in } 4 \text { sets } \\
\text { of } 8 \text { rep at } 70 \% 1 \mathrm{RM}+25 \mathrm{~min} \\
\text { treadmill at } 65-70 \% \mathrm{VO}_{2 \max }\end{array}$ & $\begin{array}{l}\text { BP monitoring } \\
\text { for } 60 \text { min and } \\
24 \text {-hour ambula- } \\
\text { tory monitoring }\end{array}$ & $\begin{array}{l}\text { Magnitude reduc- } \\
\text { tion BP similar for } \\
\text { AG and CTG } \\
\text { Longer PEH dura- } \\
\text { tion in DPB for AG }\end{array}$ \\
\hline $\begin{array}{l}\text { Pinto et } \\
\text { al. }^{23}\end{array}$ & $\begin{array}{l}30 \text { normoten- } \\
\text { sive women } \\
(23.2 \pm 4.6 \\
\text { yr })\end{array}$ & $\begin{array}{l}110.3 \pm 8.2 \\
\mathrm{~mm} \mathrm{Hg}\end{array}$ & $\begin{array}{l}69.2 \pm 7.0 \\
\mathrm{~mm} \mathrm{Hg}\end{array}$ & $\begin{array}{l}\text { SAG: } 4 \text { strength exercises in the } \\
\text { water in } 3 \text { sets of } 20 \text { s each }+18 \\
\text { min of aerobic exercises in the } \\
\text { HR from LT } \\
\text { ASG: } 18 \text { min of aerobic exercises } \\
\text { in the HR from LT }+4 \text { strength } \\
\text { exercises in the water in } 3 \text { sets of } \\
20 \text { s each }\end{array}$ & $\begin{array}{l}\text { BP monitoring } \\
\text { for } 120 \mathrm{~min}\end{array}$ & $\begin{array}{l}\text { Similar reduction } \\
\text { BP for GSA and } \\
\text { GAS in } 10 \text { min for } \\
\text { DBP and MBP }\end{array}$ \\
\hline $\begin{array}{l}\text { Tibana et } \\
\text { al. }{ }^{11}\end{array}$ & $\begin{array}{l}30 \text { normoten- } \\
\text { sive women } \\
(33.1 \pm 5.0 \mathrm{yr})\end{array}$ & $\begin{array}{l}122.7 \pm 9.2 \\
\mathrm{~mm} \mathrm{Hg}\end{array}$ & $\begin{array}{l}77.8 \pm 9.6 \\
\mathrm{~mm} \mathrm{Hg}\end{array}$ & $\begin{array}{l}\text { CG: } 60 \text { min rest } \\
\text { SG: } 6 \text { strength exercises in } 3 \text { sets } \\
\text { of } 8 \text { a } 12 \text { rep at } 80 \% 1 \mathrm{RM} \\
\text { CTG: } 30 \text { min of treadmill at } 65- \\
70 \% \text { HRR }+6 \text { strength exercises } \\
\text { in } 3 \text { sets of } 8 \text { a } 12 \text { rep at } 80 \% \\
\text { 1RM }\end{array}$ & $\begin{array}{l}\text { BP monitoring } \\
\text { for } 60 \mathrm{~min}\end{array}$ & $\begin{array}{l}\text { Greater magnitude } \\
\text { of } \mathrm{BP} \text { for GCT }\end{array}$ \\
\hline $\begin{array}{l}\text { Lovato et } \\
\text { al. }^{21}\end{array}$ & $\begin{array}{l}9 \text { normo- } \\
\text { tensive men } \\
(24.8 \pm 1.1 \mathrm{yr})\end{array}$ & $\begin{array}{l}119 \pm 3.8 \mathrm{~mm} \\
\mathrm{Hg}\end{array}$ & $\begin{array}{l}70.4 \pm 2.65 \\
\mathrm{~mm} \mathrm{Hg}\end{array}$ & $\begin{array}{l}\text { SAG: } 8 \text { strength exercises in } 3 \\
\text { sets of } 10 \text { a } 15 \text { rep at } 60 \% 1 \mathrm{RM}+ \\
50 \text { min cycle ergometer at } 60 \% \\
\mathrm{VO}_{2 \text { peak }} \\
\text { ASG: } 50 \text { min cycle ergometer } \\
\text { at } 60 \% \mathrm{VO}_{2 \text { peak }}+8 \text { strength } \\
\text { exercises in } 3 \text { sets of } 10 \text { a } 15 \text { rep } \\
\text { at } 60 \% 1 \mathrm{RM}\end{array}$ & $\begin{array}{l}\text { BP monitoring } \\
\text { for } 60 \mathrm{~min}\end{array}$ & $\begin{array}{l}\text { Magnitude reduc- } \\
\text { tion } \mathrm{BP} \text { and } \mathrm{PEH} \\
\text { duration equal } \\
\text { between groups }\end{array}$ \\
\hline $\begin{array}{l}\text { Menêzes } \\
\text { et al. }^{24}\end{array}$ & $\begin{array}{l}19 \text { hyperten- } \\
\text { sive women } \\
(57 \pm 2 \mathrm{yr})\end{array}$ & $\begin{array}{l}130 \pm 3.3 \mathrm{~mm} \\
\mathrm{Hg}\end{array}$ & $\begin{array}{l}68 \pm 2 \mathrm{~mm} \\
\mathrm{Hg}\end{array}$ & $\begin{array}{l}\text { CG: } 50 \text { min rest } \\
\text { SAG: } 7 \text { strength exercises in } 3 \\
\text { sets of } 10 \text { rep at } 50 \% 1 R M+30 \\
\text { min treadmill at } 50-60 \% \text { HRR } \\
\text { ASG: } 30 \text { min treadmill at } 50-60 \% \\
\text { HRR }+7 \text { strength exercises in } 3 \\
\text { sets of } 10 \text { rep at } 50 \% 1 \text { RM }\end{array}$ & $\begin{array}{l}\text { BP monitoring } \\
\text { for } 30 \text { min }\end{array}$ & $\begin{array}{l}\text { Magnitude reduc- } \\
\text { tion } \mathrm{BP} \text { and PEH } \\
\text { duration equal } \\
\text { between groups }\end{array}$ \\
\hline $\begin{array}{l}\text { Sac- } \\
\text { comani et } \\
\text { al. }^{22}\end{array}$ & $\begin{array}{l}10 \text { normo- } \\
\text { tensive men } \\
(24.5 \pm 1.1 \mathrm{yr})\end{array}$ & $\begin{array}{l}115.4 \pm 1.7 \\
\mathrm{~mm} \mathrm{Hg}\end{array}$ & $\begin{array}{l}70.8 \pm 2.1 \\
\mathrm{~mm} \mathrm{Hg}\end{array}$ & $\begin{array}{l}\text { CG: } 60 \text { min rest } \\
\text { AG: } 50 \text { min cycle ergometer at } \\
60 \% \mathrm{VO}_{2 \text { peak }} \\
\text { SG: } 8 \text { strength exercises in } 3 \text { sets } \\
\text { of } 12 \text { rep at } 60 \% 1 \mathrm{RM} \\
\text { ASG: } 50 \text { min cycle ergometer at } \\
60 \% \mathrm{VO}_{2 \text { peak }}+8 \text { strength exercis- } \\
\text { es in } 3 \text { sets of } 12 \text { rep at } 60 \% 1 \mathrm{RM} \\
\text { SAG: } 8 \text { strength exercises in } 3 \\
\text { sets of } 12 \text { rep at } 60 \% 1 \mathrm{RM}+ \\
50 \text { min cycle ergometer at } 60 \% \\
\mathrm{VO}_{2 \text { peak }}\end{array}$ & $\begin{array}{l}\text { BP monitoring } \\
\text { for } 60 \text { min }\end{array}$ & $\begin{array}{l}\text { Greater magnitude } \\
\text { reduction BP and } \\
\text { duration da PEH for } \\
\text { GSA e GAS } \\
\text { No differences in } \\
\text { execution order }\end{array}$ \\
\hline
\end{tabular}

Continue... 


\begin{tabular}{|c|c|c|c|c|c|c|}
\hline \multirow{2}{*}{ Study } & \multirow{2}{*}{ Participants } & \multicolumn{2}{|c|}{ Rest Blood Pressure } & \multirow{2}{*}{ Training protocol } & \multirow{2}{*}{ Duration } & \multirow{2}{*}{ Results } \\
\hline & & SBP & DBP & & & \\
\hline $\begin{array}{l}\text { Ruiz et } \\
\text { al. }{ }^{30}\end{array}$ & $\begin{array}{l}11 \text { normo- } \\
\text { tensive men } \\
(26.8 \pm 2.9 \\
\text { yr })\end{array}$ & $\begin{array}{l}122.4 \pm 8 \mathrm{~mm} \\
\mathrm{Hg}\end{array}$ & $\begin{array}{l}76.5 \pm 8.4 \\
\mathrm{~mm} \mathrm{Hg}\end{array}$ & $\begin{array}{l}\text { SG: } 8 \text { strength exer- } \\
\text { cises in } 3 \text { sets } 12 \mathrm{RM} \\
\text { AG: } 40 \text { min cycle er- } \\
\text { gometer at } 60-70 \% \text { HHR } \\
\text { ASG: } 40 \text { min cycle ergometer } \\
\text { at } 60-70 \% \text { HRR }+8 \text { strength } \\
\text { exercises in } 3 \text { sets } 12 \mathrm{RM}\end{array}$ & $\begin{array}{l}\text { BP monitoring } \\
\text { for } 60 \mathrm{~min}\end{array}$ & $\begin{array}{l}\text { Magnitude } \\
\text { reduction BP and } \\
\text { duration PEH equal } \\
\text { between groups }\end{array}$ \\
\hline
\end{tabular}

15 normoten-

Santiago sive male and $117.5 \pm 11$

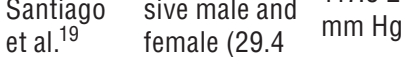
$\pm 7.3 \mathrm{yr}$ )
$68.3 \pm 7.7$ $\mathrm{mm} \mathrm{Hg}$

ASG: 30 min treadmill at $80 \%$

$\mathrm{HHR}+8$ strength exercises in 3 sets of 8 rep at $75 \% 1$ RM $\quad$ BP monitoring SAG: 88 strength exercises in 3 for $60 \mathrm{~min}$ sets of 8 rep at $75 \% 1 \mathrm{RM}+30$ Greater magnitude reduction $\mathrm{BP}$ for GAS min treadmill at $80 \% \mathrm{HHR}$

\begin{tabular}{|c|c|c|c|c|c|c|}
\hline $\begin{array}{l}\text { Teixeira et } \\
\text { al. }^{27}\end{array}$ & $\begin{array}{l}20 \text { normoten- } \\
\text { sive male and } \\
\text { female ( } 26.1 \\
\pm 1 \mathrm{yr})\end{array}$ & $\begin{array}{l}111 \pm 2 \mathrm{~mm} \\
\mathrm{Hg}\end{array}$ & $\begin{array}{l}74 \pm 1 \mathrm{~mm} \\
\mathrm{Hg}\end{array}$ & $\begin{array}{l}\text { CG: } 60 \text { min rest } \\
\text { AG: } 30 \text { min cycle ergometer at } \\
75 \% \mathrm{VO}_{2 \text { peak }} \\
\text { SG: } 6 \text { strength exercises in } 3 \text { sets } \\
\text { of } 20 \text { rep at } 50 \% 1 \mathrm{RM} \\
\text { ASG: } 30 \text { min cycle ergom- } \\
\text { eter at } 75 \% \mathrm{VO}_{2 \text { peak }}+6 \text { strength } \\
\text { exercises in } 3 \text { sets of } 20 \text { rep at } \\
50 \% 1 \mathrm{RM}\end{array}$ & $\begin{array}{l}\text { BP monitoring } \\
\text { for } 120 \mathrm{~min}\end{array}$ & $\begin{array}{l}\text { Greater magnitude } \\
\text { reduction } \mathrm{BP} \text { and } \\
\text { duration } \mathrm{PEH} \text { for } \\
\mathrm{AG}\end{array}$ \\
\hline
\end{tabular}

tensive men $120 \pm 4,5 \mathrm{~mm}$

\section{Mazzoc- 10 normo-} $\begin{array}{llll}\text { al. }^{20} & (22.6 \pm 3.7 & \mathrm{Hg} & \mathrm{mm} \mathrm{Hg}\end{array}$

\section{CG: 60 min rest}

SAG: 6 strength exercises at $90 \% 12 \mathrm{RM}+15$ min treadmill at $90 \%$ LT

ASG: 15 min treadmill at $90 \%$ LT +6 strength exercises at $90 \%$ of 12RM

CTAG: Alternate strength and aerobic exercises in sequence

CG: 60 min rest

21 normo-

\begin{tabular}{|c|c|c|c|}
\hline $\begin{array}{l}\text { Keese et } \\
\text { al. }^{26}\end{array}$ & $\begin{array}{l}21 \text { normo- } \\
\text { tensive men } \\
(20.7 \pm 0.7\end{array}$ & $\begin{array}{l}111.5 \pm 2.6 \\
\mathrm{~mm} \mathrm{Hg}\end{array}$ & $\begin{array}{l}73.9 \pm 3.6 \\
\mathrm{~mm} \mathrm{Hg}\end{array}$ \\
\hline
\end{tabular}

SAG: 6 strength exercises in 2 sets of 6 to 8 rep at $80 \% 1 \mathrm{RM}$ +30 min cycle ergometer at $50 / 65 / 80 \% \mathrm{VO}_{2 \text { peak }}$
Greater magnitude reduction $\mathrm{BP}$ for GSA

Greater duration of PEH for GSA in comparison to GCT

Magnitude equal BP reduction between groups regardless of intensity Longer duration $\mathrm{PEH}$ in $65 \%$ and $80 \% \mathrm{VO}_{2 \text { peak }}$

BP monitoring for $60 \mathrm{~min}$
CG: 60 min rest

SEAG: 7 strength exercises in 3 sets of 10 eccentric rep at 10060 hypertenSantos et sive women al. $^{31} \quad(63.3 \pm 6.2$ $162.15 \pm 7.12 \quad 88.05 \pm$ $\mathrm{mm} \mathrm{Hg}$ yr)
$4.22 \mathrm{~mm} \mathrm{Hg}$
$120 \% 10 \mathrm{RM}+20$ min treadmill at $65-75 \% \mathrm{HHR}$

STAG: 7 strength exercises in 3 sets of 10 rep at $70-90 \% 10$ RM +20 min treadmill at $65-75 \%$ HRR

\section{BP monitoring Greater magnitude for $60 \mathrm{~min}$}

$\begin{array}{llll}\text { Faraji and } & 10 \text { pre } & & \\ \text { Nikookhe- } & \text { hypertensive } & 135-150 \mathrm{~mm} & \\ \text { women }(37.6 & \mathrm{Hg} & 85-95 \mathrm{~mm} \\ \text { slat }^{25} & \pm 6.5 \mathrm{yr}) & & \mathrm{Hg} \\ & & \end{array}$

\section{CG: 6 hours in rest} CMEG: 22 min treadmill at $65 \%$ HRmax +5 strength exercises in 3 sets of 12 rep at $65 \% 1 \mathrm{RM}$ CLEG: 22 min treadmill at $40 \%$ of HRmax +5 strength exercises in 3 sets of 12 rep at $40 \% 1 \mathrm{RM}$

\section{BP monitoring Longer duration during 6 hours PEH for GCMI}

Note. CG: Control Group, AG: Aerobic group, ST: Strength group, CTG: Concurrent training group, SAG: Strength aerobic group, ASG: Aerobic-strength group, SEAG: Strength eccentric-aerobic group, STAG: Strength traditional-aerobic group, CTAG: Concurrent training alternate group, CMEG: concurrent moderate exercise group, CLEG=Concurrent light exercise group. $\mathrm{PEH}=\mathrm{Post}$ exercise hypotension. $\mathrm{HR}=$ Heart rate. $\mathrm{LT}=$ lactate threshold. $\mathrm{HRR}=$ Heart rate reserve. $\mathrm{HRmax}=$ Heart rate maximum. BP: Blood pressure, 1RM: 1 repetition maximum, SBP: Systolic blood pressure, DBP: Diastolic blood pressure, MBP: Mean blood pressure. 
Table 2. PEDro scale quality assessment of the included randomized clinical trials.

\begin{tabular}{|c|c|c|c|c|c|c|c|c|c|c|c|c|}
\hline Study & 1 & 2 & 3 & 4 & 5 & 6 & 7 & 8 & 9 & 10 & 11 & Score \\
\hline Tibana et al. ${ }^{11}$ & 1 & 1 & 0 & 1 & 0 & 0 & 0 & 1 & 1 & 1 & 1 & $6 / 10$ \\
\hline Santiago et al. ${ }^{19}$ & 1 & 1 & 0 & 1 & 0 & 0 & 0 & 1 & 1 & 1 & 1 & $6 / 10$ \\
\hline Keese et al. ${ }^{28}$ & 1 & 1 & 0 & 1 & 0 & 0 & 0 & 1 & 1 & 1 & 1 & $6 / 10$ \\
\hline Ferrari et al. ${ }^{29}$ & 1 & 1 & 1 & 1 & 1 & 1 & 1 & 1 & 1 & 1 & 1 & $10 / 10$ \\
\hline Pinto et al. ${ }^{23}$ & 1 & 1 & 0 & 1 & 0 & 0 & 0 & 1 & 1 & 1 & 1 & $6 / 10$ \\
\hline Lovato et al. ${ }^{21}$ & 1 & 1 & 0 & 1 & 0 & 0 & 0 & 1 & 1 & 1 & 1 & $6 / 10$ \\
\hline Menêzes et al. ${ }^{24}$ & 1 & 1 & 1 & 1 & 1 & 0 & 0 & 1 & 1 & 1 & 1 & $8 / 10$ \\
\hline Saccomani et al. ${ }^{22}$ & 1 & 1 & 0 & 1 & 0 & 0 & 0 & 1 & 1 & 1 & 1 & $6 / 10$ \\
\hline Ruiz et al. ${ }^{30}$ & 1 & 1 & 0 & 1 & 0 & 0 & 0 & 1 & 1 & 1 & 1 & $6 / 10$ \\
\hline Teixeira et al. ${ }^{27}$ & 1 & 1 & 0 & 1 & 0 & 0 & 0 & 1 & 1 & 1 & 1 & $6 / 10$ \\
\hline Mazzoccante et al. ${ }^{20}$ & 1 & 0 & 0 & 1 & 0 & 0 & 0 & 1 & 1 & 1 & 1 & $5 / 10$ \\
\hline Keese et al. ${ }^{26}$ & 1 & 1 & 0 & 1 & 0 & 0 & 0 & 1 & 1 & 1 & 1 & $6 / 10$ \\
\hline Santos et al. ${ }^{31}$ & 1 & 1 & 1 & 1 & 0 & 0 & 0 & 1 & 1 & 1 & 1 & $7 / 10$ \\
\hline Faraji and Nikookheslat ${ }^{25}$ & 1 & 1 & 0 & 1 & 0 & 0 & 0 & 1 & 1 & 1 & 1 & $6 / 10$ \\
\hline
\end{tabular}

\section{DISCUSSION}

The aim of this review was to summarize the acute effects of concurrent on $\mathrm{PEH}$ in hypertensive and normotensive adults. Our main results suggest that concurrent training is capable to induce $\mathrm{PEH}$ regardless of intensity and volume, as well as the order of execution of strength or aerobic training prior. The evidence pointed to a greater duration of hypotensive response induced by aerobic training when compared to concurrent and strength training. In comparison with strength training, the concurrent training led to greater duration and magnitude of the hypotensive response.

The effect of the order of execution, for example, aerobic training prior to strength training and vice versa was investigated by ${ }^{19-24}$. Santiago et al. ${ }^{19}$ evaluated normotensive men after aerobic training (treadmill for 30 minutes at $80 \%$ of heart rate reserve) follow by streng th training ( 3 sets of 8 repetitions of 8 exercises at $75 \%$ of $1 \mathrm{RM}$. The $\mathrm{PEH}$ was greater when aerobic training was performed prior to strength training ${ }^{19}$.

However, Mazzoccante et al. ${ }^{20}$ analyzed normotensive young males and found greater $\mathrm{BP}$ reduction and longer $\mathrm{PEH}$ when strength training was executed before aerobic training. Previous studies that the order of execution does not affect the magnitude and duration of the hypotensive response in normotensive men ${ }^{21,22}$, normotensive women trained in an aquatic environment ${ }^{23}$ and hypertensive women ${ }^{24}$. The training protocols performed in the included studies vary widely in volume and intensity prescribed, and, hence, the literature still lacks evidence to state whether the order of execution, as well as the volume and intensity, influence the hypotensive response.

Faraji and Nikookheslat ${ }^{25}$ submitted hypertensive women to perform an exercise on a treadmill for 22 minutes at $65 \%$ and $40 \%$ of HRmax, followed by 5 exercises in 3 sets of 12 repetitions at $65 \%$ of $1 \mathrm{RM}$ and the 
same exercises and sets but at $40 \%$ of $1 \mathrm{RM}$. The authors observed that when high intensity, great magnitude, and duration of $\mathrm{PEH}$.

Keese et al. ${ }^{26}$ also investigated the effect of different intensities of aerobic training on $\mathrm{PEH}$ in young normotensives males. The training protocol consisted of 6 strength exercises performed in 2 sets of 6 to 8 repetitions at $80 \%$ of $1 \mathrm{RM}$ and 30 minutes of aerobic training in cycle ergometer at 50,65 , and $80 \%$ of $\mathrm{VO}_{2}$ peak. All tested intensities promoted a similar decrease of BP, but $\mathrm{PEH}$ was longer when exercise prescribed at 65 and $85 \%$ of $\mathrm{VO}_{2 \text { peak }}$. In a recent review, Pescatello et al. ${ }^{9}$ analyzed several studies that investigate aerobic or strength training and concluded that when higher intensity, more expressive the hypotensive response.

Teixeira et al. ${ }^{27}$ compared the hypotensive response induced by concurrent training to other training models in young normotensive men and women. The group that performed aerobic training presented a greater reduction of $\mathrm{BP}$ and duration of $\mathrm{PEH}$ in 120 minutes after training when compared to strength training and concurrent training groups.

Keese et al. ${ }^{28}$ found similar results in normotensives, young males. However, the authors observed longer duration of $\mathrm{PEH}$ for $\mathrm{SBP}$ in aerobic and concurrent training groups in comparison to strength training, and for DPB after aerobic training. Ferrari et al. ${ }^{29}$ evaluated hypertensives older males 60 minutes after training, as well as $24 \mathrm{~h}$ later, and also found BP decrease. The evidence suggests a longer duration of hypotensive response after aerobic training when compared to the strength and/or concurrent training. Similarly, the concurrent training-induced longer duration and magnitude of $\mathrm{PEH}$ in comparison to strength training. Tibana et al. ${ }^{11}$ also reinforces that findings in a sample composed of women with metabolic syndrome.

In contrast, Saccomani et al. ${ }^{22}$ evaluated the effect of different training models (i.e., strength and aerobic training and concurrent training both aerobic follow by strength training and vice versa) on the hypotensive response in normotensive young males. Although the concurrent training has led to the greatest magnitude of the hypotensive response compared to the other training models, the order of execution did not induce a long duration of $\mathrm{PEH}$ neither high BP decrease. Nevertheless, Ruiz et al. ${ }^{30}$ found no difference between groups in similar study design and sample.

Santos et al. ${ }^{31}$ enrolled and submitted hypertensive older women to the two training protocols that are composed, respectively, by 7 strength exercises ( 3 sets of 10 eccentric repetitions at $100-120 \%$ of $10 \mathrm{RM}$ ) plus 20 minutes of a treadmill at $65-75 \%$ of HRR, and 7 strength exercises ( 3 sets of 10 repetitions at $70-90 \%$ of $10 \mathrm{RM}$ ) plus 20 minutes of treadmill at 65 $75 \%$ of HRR. The authors found a greater magnitude of BP reduction in the group that performed the eccentric strength training in addition to aerobic training. According to our strategy search, screening, and eligibility criteria, only the study of Santos et $\mathrm{al}^{31}$ investigated the effect of different combination and methods of strength training combined with aerobic training on BP.

In addition, the studies included presented, on average, 6 points in a maximum of 11 in the PEDro Scale. The methodological quality may not 
compromise the findings of the present study since the PEDro score above 5 is considered good to high quality ${ }^{18}$. However, the majority of the studies included enrolled normotensives subjects and, hence, is an important limitation of this review that should be considered. Thus, it is necessary caution to generalize these findings in relation to hypertensive subjects.

\section{CONCLUSION}

In summary, the systematic review found that concurrent training can promote $\mathrm{PEH}$ regardless of the order, volume, and intensity prescribed in the studies. Thus, concurrent training may be an effective strategy in the control of arterial hypertension. Although $\mathrm{PEH}$ presented longer duration when performed aerobic training in comparison to strength or concurrent training, the literature lack consensus about the best prescription strategy, such as aerobic training prior to strength training or vice versa.

\section{Acknowledgment}

We would like to thank Prof Victor Zuniga Dourado for encouraging research and for his commitment to ensuring high-quality training for professionals to apply exercise physiology to the interdisciplinary and interprofessional clinical practice.

\section{COMPLIANCE WITH ETHICAL STANDARDS}

\section{Funding}

This receive did not receive any specific grant from funding agencies in the public, commercial, or not-for-profit sectors. This study was funded by the authors.

\section{Ethical approval}

This research is in accordance with the standards set by the Declaration of Helsinki.

\section{Conflict of interest statement}

The authors have no conflict of interests to declare.

\section{Author Contributions}

Conceived and designed the study: DM. Performed the data extraction: DM. Analyzed the data: DM, TLVPO. Wrote the paper: DM, TLVPO.

\section{REFERENCES}

1. Organização Mundial da Saúde. Determinantes Sociais e Riscos para a Saúde, Doenças Crônicas não transmissíveis e Saúde Mental, 2017. Disponível em: https:// www.paho.org/bra/index.php?option=com_content\&view=article\&id=5253:doen cas-cardiovasculares\&Itemid=1096 [2018 Mar 26].

2. Sociedade Brasileira de Cardiologia. VII Diretriz brasileira de hipertensão arterial. Arq Bras Cardiol 2016; 107(3). 
3. He J, Gu D, Wu X, Reynolds K, Duan X, Yao C, et al. Major causes of death among men and women in China. N Engl J Med 2005;353:1124-1134.

4. Bentley LR, Koruda K, Seely EW. The metabolic syndrome inwomen. Nat Clin Pract Endocrinol Metab 2007;3:696 -704.

5. Abegunde DO, Mathers CD, Adam T, Ortegon M, Strong K. The burden and costs of chronic diseases in low-income and middle-income countries. Lancet 2007;370 (9603):1929-38.

6. Cunha F, Midgley AW, Pescatello L, Soares PP, Farinatti P. Acute hypotensive response to continuous and accumulated isocaloric aerobic bouts. Int J Sports Med 2016;37(11):855-62.

7. Ciolac EG, Guimaraes GV, D'avila VM, Bortolotto LA, Doria EL, Bocchi EA. Acute effects of continuous and interval aerobic exercise on 24-h ambulatory blood pressure in long-term treated hypertensive patients. Int J Cardiol 2009;133(3):381-7.

8. Santos LP, Moraes RS, Vieira PJ, Ash GL, Waclawovsky G, Pescatello LS, et al. Effects of aerobic intensity on ambulatory blood pressure and vascular responses in resistance hypertension: a crossover trial. J Hypertens 2016;34(7):1317-24.

9. Pescatello LS, Macdonald HV, Lamberti L, Johnson BT. Exercise for hypertension: A prescription update integrating existing recommendations with emerging research. Curr Hypertens Rep 2015;17(11):87.

10. Forjaz CL, Cardoso CG, Rezk CC, Santaella DF, Tinucci T. Postexercise hypotension and hemodynamics: the role of exercise intensity. J Sports Med Phys Fit 2004;44:54-62.

11. Tibana RA, Nascimento DC,Sousa NM, Silva RA, Vieira A, Almeida JA, et al. Efeitos do exercício de força versus combinado sobre a hipotensão pós-exercício em mulheres com síndrome metabólica. Rev Bras Cineantropom Desempenho Hum 2014;16(5):522-533.

12. Rezk CC, Marrache RC, Tinucci T, Mion D, Forjaz CL. Post-resistance exercise hypotension, hemodynamics, and heart rate variability: influence of exercise intensity. Eur J Appl Physiol 2006;98: 105-112.

13. Queiroz AC, Sousa JC, Cavalli AA, Silva ND, Costa LA, Tobaldini E, et al. Postresistance exercise hemodynamic and autonomic responses: Comparison between normotensive and hypertensive men. Scand J Med Sci Sports 2015;25(4):486-94.

14. Melo CM, Alencar AC, Tinucci T, Mion D, Forjaz CL. Postexercise hypotension induced by low-intensity resistance exercise in hypertensive women receiving captopril. Blood Press Monit 2006;11(4):183-9.

15. Macdonald JR. Potential causes, mechanisms, and implications of post exercise hypotension. J Hum Hypertens 2002;16 (4): 225-36.

16. Moher D, Liberati A, Tetzlaff J, Altman DG. Preferred reporting items forsystematic reviews and meta-analyses: the PRISMA statement. Plos Med 2009; 6(7):e1000097.

17. Shiwa SR, Costa LOP, Moser ADL, Aguiar IC, Oliveira LV. PEDro: a base de evidências em fisioterapia. Fisioter Mov 2011;24(3):523-33.

18. Moseley AM, Herbert RD, Sherrington C, Maher CG. Evidence for physiotherapy practice: a survey of the Physiotherapy Evidence Database (PEDro). Aust J Physiother 2002;48(1):43-49.

19. Santiago DA, Moraes JF, Mazzoccante RP, Boullosa DA, Simões HG, Campbell CG. Corrida em esteira e exercícios de força: efeitos agudos da ordem de realizaçãosobre a hipotensão pós-exercício. Rev Bras Educ Fís Esporte 2013;27(1):67-73.

20. Mazzoccante R, Moreira S, Sousa I, Sotero R, Simões H, Puga G, et al. Different order of combined exercises: acute effects on 24-hour blood pressure in young men. Rev Bras Educ Fís Esporte 2016;30(4):883-92.

21. Lovato NS, Anunciacao PG, Polito MD. Pressão arterial e variabilidade de freqüência cardíaca após o exercício aeróbio e com pesos realizados na mesma sessão. Rev Bras Med Esporte 2012;18(1):22-5. 
22. Saccomani MG, Figueiredo T, Kattenbraker M, Simão R, Forjaz CL; Polito MD. Blood pressure and heart rate variability responses after isolated and combined sessions of aerobic and strength exercises. Int J Sports Med 2014;15(2):178-187.

23. Pinto S, Umpierre D, Ferreira H, Nunes G, Ferrari R, Alberton C. Postexercise hypotension during different water-based concurrent training intrasession sequences in young women. J Am Soc Hypertens 2017;11(10): 653-659.

24. Menêses AL, Forjaz CL, Lima PF, Batista RM, Monteiro MF, Dias RM. Influence of endurance and resistance exercise order on the postexercise hemodynamic responses in hypertensive women. J Strength Cond Res 2015;29:612-618.

25. Faraji H, Nikookheslat SA. Effect of concurrent exercise on post-exercise hypotension in borderline hypertensive women: Influence of exercise intensity. Kinesiology 2012;44 (2):166-172.

26. Keese F, Farinatti P, Pescatello L, Cunha FA, Monteiro WD. Aerobic exercise intensity influences hypotension following concurrent exercise sessions. Int J Sports Med 2012;33:148-153.

27. Teixeira L, Dias RM, Tinucci T, Mion JD, Forjaz CL. Post-concurrent exercise hemodynamics and cardiac autonomic modulation. European Journal of Applied Physiology 2011;111(9):2069-78.

28. Keese F, Farinatti P, Pescatello L, Monteiro WA comparison of the immediate effects of resistance, aerobic, and concurrent exercise on postexercise hypotension. J Strength Cond Res. 2011;25:1429-1436.

29. Ferrari R, Umpierre D, Vogelb G, Vieira P, Santos L, Mello R, et al. Effects of concurrent and aerobic exercises on postexercise hypotension in elderly hypertensive men. Exp Gerontol 2017;98:1-7.

30. Ruiz RJ, Simao R, Saccomani MG, Casonatto J, Alexander JL, Rhea M, et al. Isolated and combined effects of aerobic and strength exercise on post-exercise blood pressure and cardiac vagal reactivation in normotensive men. J Strength Cond Res. 2011;25(3):640-5.

31. Santos E, Asano R, Filho I, Lopes N, Panelli P, Nascimento D, et al. Acute and chronic cardiovascular response to 16 weeks of combined eccentric or traditional resistance and aerobic training in elderly hypertensive women: A randomized controlled trial. J Strength Cond Res 2014;28(11):3073-3084.

\footnotetext{
(1)

Corresponding author

Thatiane Lopes Valentim Di Paschoale Ostolin

136 Silva Jardim St, Santos, SP, 5513

CEP: $11015-020$

Laboratory of Epidemiology and Human Movement,

Federal University of São Paulo,

Santos, Brazil

Email: thati.ostolin@gmail.com
} 